\title{
Examining Ontario Deaths Due to All- Terrain Vehicles, and Targets for Prevention
}

\author{
Sarah Lord, Charles H. Tator, Sandy Wells
}

\begin{abstract}
Background: All-terrain vehicle (ATV) use is increasingly popular among people of all ages. Although ATV use is known to cause significant morbidity due to head and neck trauma, there is a lack of published data detailing ATV-related fatalities. We examined all ATV-related fatalities in Ontario from 1996 - 2005 to determine the epidemiology and risk factors as a guide for improved injury prevention strategies. Methods: All ATV-related fatalities from 1996 - 2005 in Ontario were examined through Coroner's reports in the Office of the Chief Coroner of Ontario. Epidemiologic information and risk factors relating to the driver, environment, and vehicle were recorded. Results: There were 74 ATV-related fatalities from 1996 - 2005. There was only one fatality per year in 1996 and 1997 and a peak of 16 per year in 2004 and 2005. Head and neck injuries were the commonest causes of death. Males comprised $90.5 \%$ of the cases. The highest risk was from age 15 - 29, and $21 \%$ of fatalities occurred in children under 16 . Northeastern Ontario had the highest fatality rate. Conclusions: There was a major increase in the incidence of ATV-related fatalities in Ontario from 1996 - 2005 with the majority due to head trauma. Notable risk factors included alcohol use, riding at night, lack of helmet use, and excessive speed. We recommend the adoption of laws that focus on helmet requirements, a minimum driver age of 16, and certified training courses. Aggressive injury prevention efforts should be targeted toward males aged $15-29$.
\end{abstract}

RÉSUMÉ: Examen des décès dus aux véhicules tout-terrain en Ontario et cibles de prévention. Contexte : L'utilisation des véhicules tout-terrain (VTT) est de plus en plus populaire chez les individus de tout âge. Même s'il est bien connu que l'utilisation de VTT soit responsable d'une morbidité importante due aux traumatismes à la tête et au cou, peu de données ont été publiées concernant les accidents mortels dus aux VTT. Nous avons examiné tous les décès reliés aux VTT en Ontario de 1996 à 2005 pour en déterminer l'épidémiologie et les facteurs de risque afin d'améliorer les stratégies de prévention. Méthodes : Nous avons examiné les rapports du coroner concernant les décès reliés aux VTT entre 1996 et 2005 au Bureau du Coroner en chef de l'Ontario. L'information épidémiologique et les facteurs de risque reliés au conducteur, à l'environnement et au véhicule ont été colligés. Résultats : Entre 1996 et 2005, 74 décès reliés aux VTT ont été enregistrés. En 1996 et 1997, il n’y a eu qu'un seul décès par année. Le nombre de décès le plus élevé était de 16 par année en 2004 et 2005. Les blessures à la tête et au cou étaient les causes les plus fréquentes de décès et $90,5 \%$ des accidentés étaient des hommes. Le niveau de risque le plus élevé se situait entre 15 et 29 ans et $21 \%$ des décès sont survenus chez des enfants de moins de 16 ans. Le nord-est de l'Ontario avait le taux le plus élevé d'accidents mortels. Conclusions : L'incidence des accidents mortels dus aux VTT a augmenté considérablement en Ontario entre 1996 et 2005. La majorité de ces décès sont dus à un traumatisme crânien. Les facteurs de risque les plus importants étaient la prise d'alcool, l'utilisation d'un VTT la nuit, l'absence de casque protecteur et l'excès de vitesse. Nous recommandons l'adoption de lois sur le port du casque, un âge minimum de 16 ans pour la conduite d'un VTT et l'obligation de suivre un cours de conduite certifié. Des efforts vigoureux de prévention des blessures devraient cibler les hommes de 15 à 29 ans.

Can. J. Neurol. Sci. 2010; 37: 343-349

All-terrain vehicle (ATV) use has become increasingly popular among Canadians of all ages, and ATV-related injuries and fatalities are of major public concern. There were almost one million ATVs registered in Canada in 2005, a number that is projected to increase by more than $5.9 \%$ annually until $2010^{1}$. Two-thirds of ATVs are used for recreational purposes, and onethird for farming and other industrial settings ${ }^{1}$. In any setting, ATVs are designed for off-road use and typically have large, low-pressure tires, a seat straddled by the rider, and a high centre of gravity. ${ }^{2}$ All-terrain vehicle usually lack seatbelts, airbags, and encasement by walls or roofs. They can weigh more than $250 \mathrm{~kg}^{3}$ and reach speeds greater than $90 \mathrm{~km} / \mathrm{h}$. ${ }^{4,5}$ These features make ATV riders prone to head and neck injuries, especially by rollover or driver ejection after collision. The Canadian Institute for Health Information (CIHI) reported a 50\% increase in ATVrelated hospitalizations from 1996 to $2001^{6}$.

Since their introduction in Canada in the 1970's, the configuration of ATVs has changed because of consent decrees

From the Doctor of Medicine Program (SL); Department of Surgery, Division of Neurosurgery (CHT), Toronto Western Hospital and University of Toronto; National Injury Prevention Program (SW), Toronto, Ontario, Canada.

Received September 21, 2009. Final Revisions Submitted November 11, 2009. Correspondence to: Sarah Lord, Doctor of Medicine Program, University of Toronto, 124 Ranleigh Avenue, Toronto, Ontario, M4N 1W9, Canada. 
signed in the United States in 1988 after the U.S. Consumer Product and Safety Commission deemed three-wheeled ATVs unsafe due to their high rollover potential. Although threewheeled models are no longer manufactured or distributed in North America ${ }^{2,7}$ the use of pre-existing three-wheelers remains legal. For currently manufactured four-wheeled ATVs, a voluntary standard was adopted by manufacturers to provide safety messages in owner's manuals, warning labels, and the following age-related guidelines: under $70 \mathrm{cc}$ engine for children less than 12; and under $90 \mathrm{cc}$ engine for children less than $16^{2}$.

Many of the most catastrophic ATV-related injuries result from significant head trauma. Major risk factors associated with these ATV injuries and fatalities have been addressed in several published recommendations regarding ATV safety, including position statements by the Canadian Paediatric Society, American Academy of Pediatrics, American Academy of Orthopedic Surgeons, and the American College of Surgeons..$^{8-10}$ Risk factors cited include riding at night, riding with passengers, driving under the influence of alcohol or drugs, failure to wear a proper helmet and other safety equipment, riding three-wheeled vehicles, and lack of training..$^{9-11}$ Emphasis has also been placed on the prevalence of ATV-related injuries and fatalities in children, and the cited risks include lack of muscle coordination, small body size, and immature judgment, factors that collectively make it difficult for children to safely control an ATV. ${ }^{4,11-46}$ Several groups recommend that children under 16 should be prohibited from riding ATVs ${ }^{8-11}$ Public concern about injuries in Canada has resulted in recent legislative changes in some provinces.

Although there have been several studies of ATV-related fatalities in the United States, there is very little published data on the epidemiology of ATV-related fatalities in Canada. Improved understanding of the epidemiology and risks of ATV- related fatalities allows targeting of injury prevention efforts including legislation. The present study documents the epidemiology of ATV-related fatalities in Ontario, 1996 - 2005, and identifies current risk factors and targets for injury prevention.

\section{Methods}

Data on ATV-related fatalities were obtained at the Office of the Chief Coroner of Ontario which collects records from Ontario's regional coroners, including all deaths from traumatic and sudden, unexplained events ${ }^{47}$. A list of ATV-related deaths from 1996 - 2005 was generated (2005 was the most recent year with complete data at the time of this study in 2008). The records included death certificates, police reports, pathology and autopsy reports, and the regional coroner's summary, and all were reviewed for each case identified. All ATVs (three wheels or more) were included; other motorized vehicles such as go-carts, dune buggies, and snowmobiles were excluded because they are not typically included in the definition of an ATV.

In addition to demographic information, the following information regarding potential risk factors was collected: cause of death, mechanism of injury, helmet use, alcohol or drug involvement, number of wheels, vehicle model, previous condition of the vehicle (determined by the police in most fatalities), evidence of excessive speeding, reduced visibility, type of terrain, month, time of day, and regional location. We determined whether the ATV was used for recreation or work, and whether the deceased was the driver, passenger, pedestrian, or another motorist.

\section{RESUlts}

Eighty-five ATV-related deaths were identified from 1996 2005, and files on 83 deaths were available for review. Two files

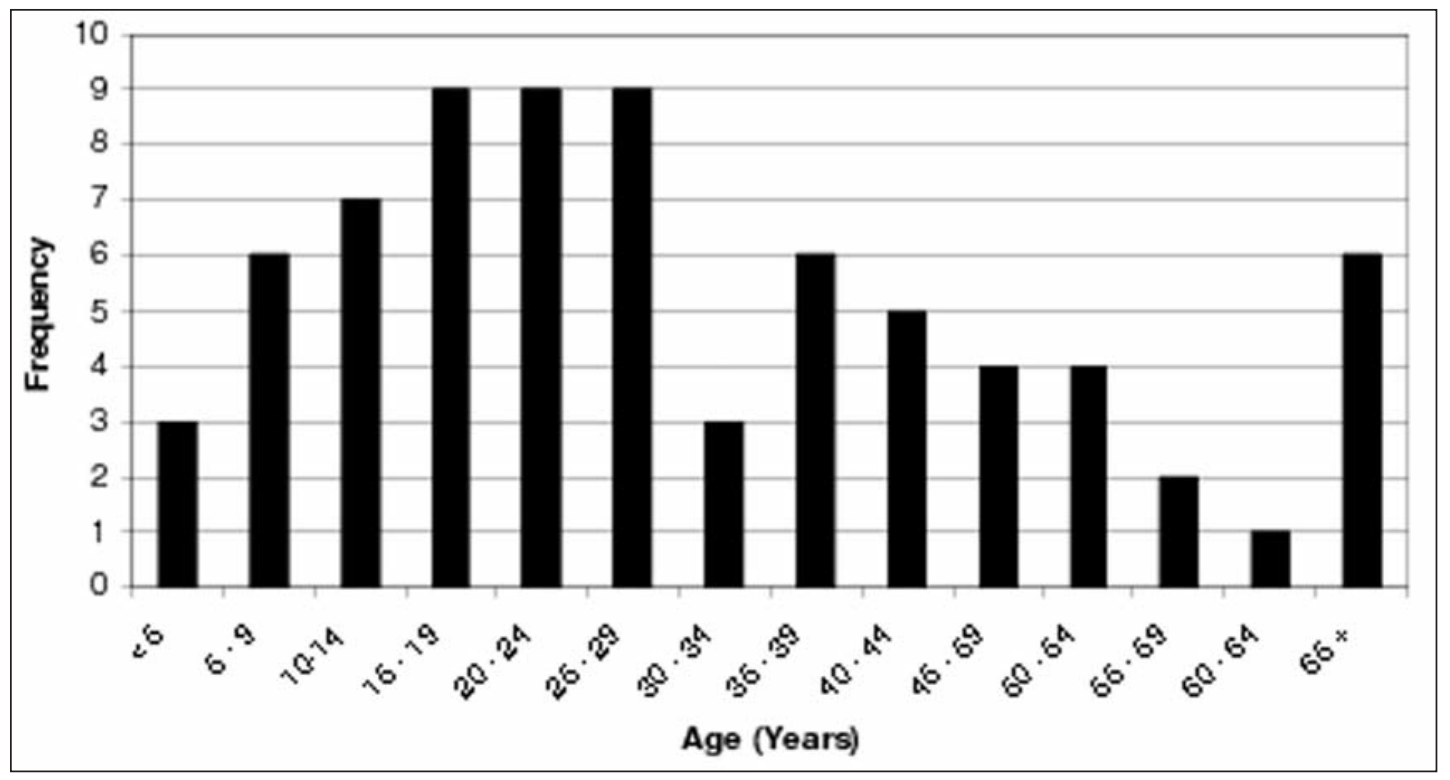

Figure: Frequency of ATV fatalities in Ontario by age group, 1996 - 2005. 
Table 1: ATV fatality rate by year in Ontario, 1996 -2005

\begin{tabular}{l|c|c|c}
\hline & $\begin{array}{c}\text { Ontario } \\
\text { population } \\
\text { (rounded to } \\
\text { nearest 100) }\end{array}$ & $\begin{array}{c}\text { Number of } \\
\text { fatalities } \\
\text { (n-') } 4)\end{array}$ & $\begin{array}{c}\text { Deaths per } \\
100,000 \\
\text { population }\end{array}$ \\
\hline 1996 & $11,083,100$ & 1 & 0.0090 \\
\hline $199 \%$ & $11,228,300$ & 1 & 0.0089 \\
\hline 1998 & $11,36 \%, 000$ & 2 & $0.01 \%$ \\
\hline 1999 & $11,506,400$ & 3 & 0.0261 \\
\hline 2000 & $11,685,400$ & 5 & 0.0428 \\
\hline 2001 & $11,89 \%, 600$ & 9 & $0.0 \% 56$ \\
\hline 2002 & $12,102,000$ & 16 & 0.132 \\
\hline 2003 & $12,259,600$ & 5 & 0.0408 \\
\hline 2004 & $12,420,300$ & 16 & $0.12 \%$ \\
\hline 2005 & $12,565,400$ & 16 & \\
\hline MEAN & $11,811,500$ & & \\
\hline & & & \\
\hline
\end{tabular}

were unavailable because they had been borrowed for either legal or research purposes. Nine of the 83 were excluded because the cause of death was unrelated to a traumatic injury involving an ATV: four due to myocardial infarction while lifting or moving an ATV; four due to myocardial infarction while riding an ATV; and one due to an ATV-related head injury incurred prior to the study period. Thus, 74 deaths were included in the study.

Table 1 shows that the death rate increased dramatically from 1996 to 2005 . The mean incidence of death was 7.4 per year, and the mean death rate was 0.0627 per 100,000 Ontarians. The location of the fatalities based on the Local Health Integration Networks (LHINs) developed by the Ontario Ministry of Health and Long-Term Care ${ }^{43}$ indicates that the largest number of fatalities occurred in the North East LHIN $(20.3 \%, n=15)$. Death rates according to the number of registered ATVs in Ontario could not be calculated because ATVs are not listed separately in the registration statistics and are combined with other off-highway vehicles (eg. mopeds, dirt bikes).

Males comprised $90.5 \%(n=67)$ of the cases. The mean age of all fatalities was 30.7 years, and the age range was 4 months to 93 years. The highest number of fatalities occurred in the 15-19, 20-24, and 25-29 year old groups, with an equal number of fatalities $(n=9)$ in each (Figure 1). Sixteen fatalities $(21.6 \%)$ occurred in children less than 16 years-of-age. Table 2 shows the cause of death, with head and neck injuries due to blunt force trauma being the most common $(51.4 \%)$.

Drivers comprised $81.1 \%(\mathrm{n}=60)$ of the fatalities, $14.9 \%(\mathrm{n}$ $=11)$ were passengers, $2.7 \%(n=2)$ were other motorists involved in a collision with an ATV (one snowmobile, one motorcycle); and one pedestrian (1.4\%) was struck by an ATV. The highest number of fatalities occurred in July and August, each with 11, and December through March had the lowest rates with two fatalities each month. Incidents on public roads caused the highest proportion of fatalities $(45.9 \%)$, followed by off-road and other types of terrain. The mechanisms of injury, such as ATV rollover or striking immobile objects, is shown in Table 3.

The data for other risk factors are summarized in Table 4. Alcohol use, lack of a helmet, excessive speed and suboptimal lighting were major factors. Driving at excessive speed was significantly more likely in drivers 29 years of age and younger compared with older riders $\left(x^{2}=4.39, p<0.05\right)$. Alcohol use was much more frequent in fatalities that occurred after dark $\left(\mathrm{x}^{2}=\right.$

Table 2: Frequency of ATV fatalities in Ontario by medical cause of death, 1996-2005

\begin{tabular}{|c|c|c|}
\hline $\begin{array}{l}\text { Medical Cause of } \\
\text { Death }\end{array}$ & Frequency & Percent ( 8 ) \\
\hline Motor Vehicle & & \\
\hline $\begin{array}{l}\text { Injuries / } \\
\text { Blunt Force Trauma: }\end{array}$ & $\%$ & 94.6 \\
\hline $\begin{array}{l}\text { Head and Neck } \\
\text { Injuries }\end{array}$ & 38 & $(51.4)$ \\
\hline Head Injuries & 28 & $(73.6)$ \\
\hline Neck injuries & s & $(13.2)$ \\
\hline $\begin{array}{l}\text { Head and neek } \\
\text { Injuries }\end{array}$ & 5 & $(13.2)$ \\
\hline Chest Injuries & 13 & $(18.6)$ \\
\hline Asphyxia & 5 & $(6.8)$ \\
\hline $\begin{array}{l}\text { Multiple } \\
\text { Injuries }\end{array}$ & 14 & $(20.0)$ \\
\hline Drowning & 2 & $2 . \%$ \\
\hline Hypothermia & 1 & 1.4 \\
\hline Other & 1 & 1.4 \\
\hline TOTAL & $1 / 4$ & $-\cdots$ \\
\hline
\end{tabular}


14.03, $\mathrm{p}<0.001)$ than during the day. The rate of alcohol use among those fatalities due to head and neck injuries was approximately equal to the overall rate of alcohol use in the total fatalities $(47 \%)$.

Information about passengers was available for 72 of the 74 cases: $75 \%(n=54)$ occurred when the ATV was driven by a single rider, while $25 \%(\mathrm{n}=18)$ occurred with one or more passengers. Of the 74 fatalities, the driver died in $81 \%(n=60)$, and in $19 \%(n=14)$ the passenger died. Only $5 \%(n=4)$ of cases involved individuals who were using the ATV for work-related purposes (eg. industrial, farm work), while $73 \%(n=54)$ were non-work related (eg. recreation, transportation). In the remaining $22 \%(n=16)$, the purpose of vehicle use was uncertain in the records.

Information about vehicle defects prior to the fatal collision was available for 36 cases, and only $14 \%(n=5)$ reported a defect: brake problems in three; broken lights in one; and vehicle body damage in one. Information about the size of the vehicle was available for 12 of the 16 fatalities in youths less than 16 yearsof-age, and in all but one, the youths were driving adult-sized vehicles. In the remaining case, the vehicle was reported as "youth sized", but it was not clear whether it was the smallest size (under $70 \mathrm{cc}$ ) recommended for the age of the child.

\section{Discussion}

\section{Incidence and Epidemiology}

The annual incidence of ATV-related fatalities in Ontario rose markedly over the 1996-2005 period from one death in 1996 to 16 in 2005. Our previous study of ATV fatalities in Ontario from 1986-1995 based on both hospital records and coroner's reports showed an annual incidence of only four. ${ }^{48}$ Relative to surrounding years, 2003 had a lower fatality rate at only five deaths during that year; despite investigation in to possible reasons such as legislation changes or public campaigns, we have not found a clear explanation for this anomaly. The North East LHIN was the region with the highest number of fatalities over the study period (20.2\%), which parallels the overall higher rate of traumatic death and the relatively high prevalence of ATV use in this region. ${ }^{49}$

\section{Risk Factors}

We analyzed risk factors for fatality related to the driver, environment and vehicle.

Driver: Driver risk factors were age, gender, alcohol use, helmet use, and driving practices (speeding, driving alone). The majority of fatalities occurred in males (over 90\%), and the highest incidence was in 15-29 year olds. It is difficult to ascertain the male:female ratio for ATV riding in Ontario, although data from the United States suggests males comprise about two-thirds of ATV riders ${ }^{50}$, and therefore, the frequency of fatalities is disproportionately higher among males which echoes other motorized recreational vehicles ${ }^{46}$.

As was found in the study by Helmkamp et al of youth ATV fatalities for a similar time period in West Virginia ${ }^{51}$, almost onequarter $(21.6 \%)$ of the deaths in the current study were youths under 16 years-of-age. Indeed, we found that youths under 19 years-of-age comprised about one-third of the ATV-related fatalities, which mirrors CIHI's 2003 report on the incidence of all ATV-related injuries (fatal and non-fatal) in Canada. ${ }^{52}$
Table 3: Mechanism of injury for ATV fatalities in Ontario, 1996-2005

\begin{tabular}{|c|c|c|}
\hline Mechanism of Injury & Frequency & Percent ( $(8)$ \\
\hline $\begin{array}{l}\text { Collision with } \\
\text { immobile object }\end{array}$ & 16 & 21.6 \\
\hline $\begin{array}{l}\text { Collision with } \\
\text { other moving } \\
\text { vehicle }\end{array}$ & 15 & 20.3 \\
\hline ATV rollover & 10 & 13.5 \\
\hline $\begin{array}{l}\text { Failed to negotiate } \\
\text { turn }\end{array}$ & 9 & 12.1 \\
\hline Ejection from ATV & 9 & 12.1 \\
\hline $\begin{array}{l}\text { ATVing on steep } \\
\text { incline }\end{array}$ & 7 & 9.5 \\
\hline Drove into ditch & 4 & 5.4 \\
\hline Hit by ATV & 3 & 4.1 \\
\hline $\begin{array}{l}\text { Drove into body of } \\
\text { water }\end{array}$ & 1 & 1.4 \\
\hline Total & $7 / 4$ & --- \\
\hline
\end{tabular}

Similar to previous studies that emphasized alcohol use as a key risk factor ${ }^{53,54}$, we found that alcohol was involved in $47.3 \%$ of fatalities in Ontario. The West Virginia study also documented alcohol involvement in about half the cases ${ }^{52}$. Identifying blood alcohol concentrations (BACs) above the legal limit has limitations since most blood samples were taken hours after injury or death, which underestimates the BAC at the time of collision. We did not find a significant relationship between gender and alcohol involvement, most likely due to the relatively low female sample size.

A high percentage $(58.1 \%)$ of the fatalities had head injuries and $63.3 \%$ of all fatalities were unhelmeted. Of the fatalities due to head and/or neck injuries, helmets were absent at least $53 \%$ of the time (with an additional $10.5 \%$ of the remaining fatalities having no information regarding helmet use available). Helmet use did not significantly alter the incidence of head or neck injuries causing or contributing to death most likely because the velocity of the ATVs and force on the head exceeded the protection helmets can provide. Indeed, helmets are likely more effective in reducing injury severity of lower force than those causing fatality. The present study confirmed that younger riders (29 years-of-age or less) were more often driving at excessive speed $^{50}$.

Environment: The highest proportion of fatalities occurred on public roads and intersections (46\%), followed by off-road terrain. The most common mechanism of injury was collision with another vehicle, followed by striking an obstacle, most 
Table 4: Risk factors for ATV fatalities in Ontario, 1996-2005

\begin{tabular}{|c|c|c|}
\hline Risk factor & Frequency & $\begin{array}{l}\text { Percent of those } \\
\text { measured/ } \\
\text { documented }(\%)\end{array}$ \\
\hline $\begin{array}{l}\text { ALCOHOL } \\
\mathrm{BAC}>0.08\end{array}$ & 21 & $(38.2)$ \\
\hline $\mathrm{BAC}<0.08$ & 8 & $(14.5)$ \\
\hline $\begin{array}{l}\text { Detected but no } \\
\text { specific measure } \\
\text { given }\end{array}$ & 6 & $(10.9)$ \\
\hline Undetected & 20 & $(36.4)$ \\
\hline Not Measured & 19 & - \\
\hline $\begin{array}{l}\text { OTHER DRUGS } \\
\text { Detected } \\
\text { Undetected } \\
\text { Not Measured } \\
\end{array}$ & $\begin{array}{r}6 \\
9 \\
59 \\
\end{array}$ & $\begin{array}{c}(40.0) \\
(60.0) \\
- \\
\end{array}$ \\
\hline $\begin{array}{l}\text { HELMET USE } \\
\text { Helmet Worn } \\
\text { Helmet Not Worn } \\
\text { Helmet Use Unclear }\end{array}$ & $\begin{array}{l}22 \\
38 \\
14\end{array}$ & $\begin{array}{c}(36.7) \\
(63.3) \\
-\end{array}$ \\
\hline $\begin{array}{l}\text { EXCESSIVE SPEED } \\
\text { Yes } \\
\text { No } \\
\text { Unclear }\end{array}$ & $\begin{array}{l}21 \\
14 \\
39 \\
\end{array}$ & $\begin{array}{c}(60.0) \\
(40.0) \\
- \\
\end{array}$ \\
\hline $\begin{array}{l}\text { DRIVING ALONE } \\
\text { ATVing alone } \\
\text { ATVing in group } \\
\text { Unclear }\end{array}$ & $\begin{array}{l}24 \\
49 \\
1 \\
\end{array}$ & $\begin{array}{c}(32.9) \\
(67.1) \\
- \\
\end{array}$ \\
\hline $\begin{array}{l}\text { DECREASED } \\
\text { VISIBILITY } \\
\text { Yes } \\
\text { No } \\
\text { Unclear }\end{array}$ & $\begin{array}{c}4 \\
29 \\
41\end{array}$ & $\begin{array}{c}(12.1) \\
(87.9) \\
-\end{array}$ \\
\hline $\begin{array}{l}\text { SUBOPTIMAL } \\
\text { LIGHTING } \\
\text { Yes } \\
\text { No } \\
\text { Unclear } \\
\end{array}$ & $\begin{array}{c}24 \\
42 \\
8 \\
\end{array}$ & $\begin{array}{c}(36.4) \\
(63.6) \\
- \\
\end{array}$ \\
\hline $\begin{array}{l}\text { NUMBER OF WHEELS } \\
3 \text { wheels } \\
4 \text { wheels } \\
6 \text { wheels } \\
\text { Uncertain }\end{array}$ & $\begin{array}{c}6 \\
56 \\
3 \\
9 \\
\end{array}$ & $\begin{array}{c}(9.2) \\
(86.2) \\
(4.6) \\
- \\
\end{array}$ \\
\hline $\begin{array}{l}\text { PRIOR CONDITION OF } \\
\text { VEHICLE } \\
\text { Defect Present } \\
\text { No Defect } \\
\text { No vehicle } \\
\text { inspection } \\
\text { documented }\end{array}$ & $\begin{array}{c}5 \\
31 \\
38\end{array}$ & $\begin{array}{c}(13.9) \\
(86.1) \\
-\end{array}$ \\
\hline
\end{tabular}

commonly a tree. Although a small number of collisions with other vehicles occurred on trails (eg. one with a snowmobile), the majority occurred on roads. These findings indicate the importance of preventing ATV use on roads in close proximity to cars and trucks. About one-third of fatalities occurred after dusk and before dawn, indicating that night driving is another important risk factor for injury prevention including legislation.

Vehicle: Vehicle size is recognized as a significant risk factor for injuries and fatalities in the paediatric population. All but one of the fatalities in the under 16 age group with known vehicle model information involved adult-sized ATVs, confirming that adult-sized ATVs pose a risk to children. It is unproven whether child-sized ATVs pose less risk for injury or fatality; therefore, it is not possible to evaluate the validity or effectiveness of current industry recommendations for youth and ATV size. Vehicle defects did not seem to play a significant role in most fatalities, as reports of vehicle defects prior to the incident were present in only five cases $(13.9 \%)$ for which there were official vehicle inspections conducted after the fatalities occurred (Table 4).

\section{Injury Prevention Recommendations including Legislation}

Compared to some provinces, Ontario legislation does not restrict the use of ATVs on public roads and has minimal restrictions on children under 16 . We will report separately on current ATV legislation in other provinces and territories of Canada. Ontario requires ATV drivers to hold a driver's license if ATVs are driven on public roads and highways, similar to legislation in Quebec, Saskatchewan, Nova Scotia, British Columbia, and Manitoba. In Ontario, ATV driving on private roads or off-road requires no licensing. In addition, helmet laws in Ontario only refer to highway use. Although we did not find a significant association between death from head injury and lack of helmet use, in over half the fatalities helmets were absent. Therefore, we recommend mandatory helmets for all ATV use on and off roads, in all provinces and territories, as is currently legislated in Nova Scotia, New Brunswick, Quebec, and Nunavut. Helmets used should be the same type certified for use with motorcycles. Furthermore, the risk of fatal head injury in spite of helmet use must be emphasized so that riders understand that helmets can minimize injury but that with enough force, catastrophic injuries may not be prevented. Indeed, helmets cannot replace safe driving practices.

The Canadian Paediatric Society guidelines, published in $2004^{9}$, recommend that children under 16 years-of-age should not operate or ride as passengers on ATVs. The American College of Surgeons recommended in 2009 that "Recreational use of ATVs should be limited to people who have licenses to operate other motorized vehicles". ${ }^{8}$ We found $21.6 \%(n=16)$ of ATV-related fatalities were in children less than 16-years-old. The effectiveness of manufacturers' recommendations for ATV size and rider age are unproven (under 70cc engine for children under 12; under 90cc engine for children under $16^{2}$ ), and our data on childhood fatalities are so compelling that we support the incorporation of the Canadian Paediatric Society guidelines into legislation.

Although the manufacture of three-wheeled ATVs was banned in the late 1980's, it is not illegal to ride existing threewheelers. In our study almost $10 \%$ of the ATVs in the fatalities were three-wheelers, a relatively high number given that two decades have passed since their manufacture. This proportion of fatalities is high enough to recommend, in light of other supporting evidence, , $11,14,21,38$ that the use of three-wheelers should be banned. 
With ATV use likely to continue its upward trend, we recommend that health professionals take an active role in injury prevention, particularly in communities where ATV use is prevalent. For example, primary care physicians should educate patients about helmet use in recreational activities, especially those involving motorized vehicles. Current legislation in all provinces except Quebec permits children to ride ATVs under supervision; therefore, parents must be educated about the dangers of ATV use in the children. A harm reduction approach should be adopted emphasizing the importance of minimizing risk by using helmets, driving in daylight, and taking training courses, especially for children and males between 15 and 29 years old. School-based safety education programs may also be beneficial in communities with high rates of ATV use. As well, closer examination of potential vehicle improvements, such as brighter lights, should be investigated given the prevalence of nighttime collisions. The public must understand that death is often associated with head trauma and occurs even when helmets are worn if the force of impact is sufficiently great.

\section{Study Limitations}

Data for the current study depended on the completeness of the coroners' reports. We found that some information relevant for injury prevention was not always collected, such as the use of child size ATVs. We recommend improved and standardized data collection about ATV fatalities by the police, emergency medical personnel, ATV associations and coroners. Furthermore, documentation of the type of helmets worn during catastrophic events would allow greater understanding of whether helmet type is a contributory factor in their effectiveness. Standardized data collection would enhance the analysis of ATV injuries and deaths in Canada and allow improvement in injury prevention strategies including legislation. Finally, it is important to note that statistical data showing the number of ATVers or ATVs in Ontario during the study period is an important denominator for understanding the impact of injury and fatality data. Unfortunately, this data is not available due to a significant number of unregistered ATVs, as well as grouping of various types of off-road vehicles when registration statistics are compiled.

\section{Conclusions}

To aid in future research, we recommend that all ATVs be required to be registered in all provinces and that this data remains separate from other off-road vehicle types.

\section{ACKNOWLEDGEMENTS}

This research was supported by a grant to ThinkFirst, Canada from the Ontario Neurotrauma Foundation. Sarah Lord was a summer intern at ThinkFirst, Canada when she performed this research. The authors thank Dr. Barry McLellan, former Chief Coroner of the Province of Ontario at the time the data was collected for support of this project, and to June Lindsell of the Office of the Chief Coroner who facilitated data collection.

\section{REFERENCES}

1. Gunther P. Alberta Off-Highway Vehicle Association [Internet]. Nepean: Smith Gunther Associates; c2007-2009 [cited 2008 Sep
1]. The economic impact of all terrain vehicle recreation in Canada: national, provincial, and territorial. Available from: http://www.aohva.com.

2. Rodgers GB. All-terrain vehicle injury risks and the effects of regulation. Accid Anal Prev. 1993;25:335-46.

3. Rodgers GB, Adler P. Risk factors for all-terrain vehicle injuries: a national case-control study. Am J Epidemiol. 2001;153:1112-8.

4. Canadian Paediatric Society, Accident Prevention Committee. Two, three and four-wheel unlicensed off-road vehicles. Accident Prevention Committee, Canadian Paediatric Society. CMAJ. 1987;136:119-20.

5. Brandenburg MA. All-terrain vehicle injuries: a growing epidemic. Ann Emerg Med. 2004;43:536-7.

6. Lai T. ATV injuries rise by $50 \%$ as other types decline. CMAJ. 2003;168:1169.

7. Axelband J, Stromski C, McQuay N, Jr., Heller M, Axelband J, Stromski C, et al. Are all-terrain vehicle injuries becoming more severe? Accid Anal Prev. 2007;39:213-5.

8. Statement on all-terrain vehicle injuries. Bull Amer Coll of Surg. 2009;94(2):37-8

9. Canadian Pediatric Society. Preventing injuries from all-terrain vehicles. J Paediatr Child Health. 2004;9(5):337-40.

10. American Academy of Orthopaedic Surgeons [Internet]. Rosemont: The Association; c1995-2009 [updated 2005 Jun; cited 2008 Jul 20]. Position Statement: All-Terrain Vehicles, 2005; [about 3 screens]. Available from: http://www.aaos.org/about/papers/ position/1101.asp

11. American Academy of Pediatrics Committee on Injury and Poison Prevention. All-terrain vehicle injury prevention: two, three and four-wheeled unlicensed motor vehicles. Pediatrics. 2000;105: 1352-4.

12. Alawi K, Lynch T, Lim R. All-terrain vehicle major injury patterns in children: a five-year review in Southwestern Ontario. CJEM. 2006;8(4):277-80.

13. Aitken ME, Graham CJ, Killingsworth JB, Mullins SH, Parnell DN, Dick RM. All-terrain vehicle injury in children: strategies for prevention. Inj Prev. 2004;10:303-7.

14. American Academy of Pediatrics Committee on Accident and Poison Prevention: All-terrain vehicles: two-, three-, and fourwheeled unlicensed motorized vehicles. Pediatrics. 1987;79:306-8.

15. Bercher DL, Staley K, Turner LW, Aitken M. Pediatric injuries resulting from use of all-terrain vehicles. J Ark Med Soc. 2001;97:351-3

16. Bhutta ST, Greenberg SB, Fitch SJ, Parnell D. All-terrain vehicle injuries in children: injury patterns and prognostic implications. Pediatr Radiol. 2004;34:130-3.

17. Boswell WC, Boyd CR, Schaffner D, Williams JS, Frantz E. Prevention of pediatric mortality from trauma: are current measures adequate? South Med J. 1996;89:218-20.

18. Brown RL, Koepplinger ME, Mehlman CT, Gittelman M, Garcia VF. All-terrain vehicle and bicycle crashes in children: epidemiology and comparison of injury severity. J Pediatr Surg. 2002;37:375-80.

19. Cardoso ER, Pyper A. Pediatric head injury caused by off-road vehicle accidents. Can J Neurol Sci. 1989;16:336-9.

20. Cvijanovich NZ, Cook LJ, Mann NC, Dean JM. A population-based assessment of pediatric all-terrain vehicle injuries. Pediatrics. 2001; 108:631-5.

21. Dolan MA, Knapp JF, Andres J. Three-wheel and four-wheel allterrain vehicle injuries in children. Pediatrics. 1989;84:694-8.

22. Gittelman MA, Pomerantz WJ, Groner JI, Smith GA. Pediatric allterrain vehicle-related injuries in Ohio from 1995 to 2001: using the injury severity score to determine whether helmets are a solution. Pediatrics. 2006;117:2190-5.

23. Graham J, Dick R, Parnell D, Aitken ME. Clothesline injury mechanism associated with all-terrain vehicle use by children. Pediatr Emerg Care. 2006;22:45-7.

24. Helmkamp J, Lawrence BA. The economic burden of all-terrain vehicle-related pediatric deaths in the United States. Pediatrics. 2007;119:223-5. 
25. Humphries RL, Stone CK, Stapczynski JS, Florea S. An assessment of pediatric all-terrain vehicle injuries. Pediatr Emerg Care. 2006;22:491-4.

26. Jones NE. Prevention of childhood injuries. Part II: Recreational injuries. Pediatr Nurs. 1992;18:619-21.

27. Keenan HT, Bratton SL. All-terrain vehicle legislation for children: a comparison of a state with and a state without a helmet law. Pediatrics. 2004;113:e330-4.

28. Kelleher CM, Metze SL, Dillon PA, Mychaliska GB, Keshen TH, Foglia RP. Unsafe at any speed--kids riding all-terrain vehicles. J Pediatr Surg. 2005;40:929-35.

29. Killingsworth JB, Tilford JM, Parker JG, Graham JJ, Dick RM, Aitken ME. National hospitalization impact of pediatric allterrain vehicle injuries. Pediatrics. 2005;115:e316-21.

30. Kriel RL, Sheehan M, Krach LE, Kriel HD, Rolewicz TF. Pediatric head injury resulting from all-terrain vehicle accidents. Pediatrics. 1986;78:933-5.

31. Lim GW, Belton KL, Pickett W, Schopflocher DP, Voaklander DC. Fatal and non-fatal machine-related injuries suffered by children in Alberta, Canada, 1990-1997. Am J Ind Med. 2004:45:177-85.

32. Lister DG, Carl J, 3rd, Morgan JH, Denning DA, Valentovic M, Trent B, et al. Pediatric all-terrain vehicle trauma: a 5-year statewide experience. J Pediatr Surg. 1998;33:1081-3.

33. Little DC, Vermillion JM, Dikis EJ, Little RJ, Custer MD, Cooney DR. Life on the farm-children at risk. J Pediatr Surg. 2003;38:804-7.

34. Lynch JM, Gardner MJ, Worsey J. The continuing problem of allterrain vehicle injuries in children. J Pediatr Surg. 1998;33:32932.

35. Mangano FT, Menendez JA, Smyth MD, Leonard JR, Narayan P, Park TS. Pediatric neurosurgical injuries associated with allterrain vehicle accidents: a 10-year experience at St. Louis Children's Hospital. J Neurosurg. 2006;105:2-5.

36. Murphy N, Yanchar NL. Yet more pediatric injuries associated with all-terrain vehicles: should kids be using them? J Trauma. 2004;56:1185-90.

37. Nelson TA, Hafner JW, Jr. Emergency department pediatric allterrain vehicle injuries in West Central Illinois. Pediatr Emerg Care 2005;21:719-24

38. Ruddy RM, Selbst SM. Three-wheeled vehicle injuries in children. Am J Dis Child. 1990;144:71-3.

39. Russell A, Boop FA, Cherny WB, Ligon BL. Neurologic injuries associated with all-terrain vehicles and recommendations for protective measures for the pediatric population. Pediatr Emerg Care. 1998;14:31-5.
40. Shults RA, Wiles SD, Vajani M, Helmkamp JC. All-terrain vehiclerelated nonfatal injuries among young riders: United States, 2001-2003. Pediatrics. 2005; 116:e608-12.

41. Stevens WS, Rodgers BM, Newman BM. Pediatric trauma associated with all-terrain vehicles. J Pediatr. 1986;109:25-9.

42. Upperman JS, Shultz B, Gaines BA, Hackam D, Cassidy LD, Ford $\mathrm{HR}$, et al. All-terrain vehicle rules and regulations: impact on pediatric mortality. J Pediatr Surg. 2003;38:1284-6.

43. Warda L, Klassen TP, Buchan N, Zierler A. All terrain vehicle ownership, use, and self reported safety behaviours in rural children. Inj Prev. 1998;4:44-9.

44. Yanchar NL, Kennedy R, Russell C. ATVs: motorized toys or vehicles for children? Inj Prev. 2006;12:30-4.

45. Yuma PJ, Maxson RT, Brown D. All-terrain vehicles and children: history, injury burden, and prevention strategies. J Pediatr Health Care. 2006;20:67-70.

46. Tator CH. Overview of the results of the Ontario study, 1986-1995. In: Tator $\mathrm{CH}$, editors. Catastrophic injuries in sports and recreation, causes and prevention: a Canadian study. Toronto: University of Toronto Press; 2008. p. 21-57.

47. Coroners Act, R.S.O. 1990 , c. C.37. Available at: http://www.elaws.gov.on.ca/html/statutes/english/elaws_statutes_90c37_e.ht $\mathrm{m}$.

48. Heinicke S, Tator $\mathrm{CH}$. All terrain vehicle riding. In: Tator $\mathrm{CH}$, editors. Catastrophic injuries in sports and recreation, causes and prevention: a Canadian study. Toronto: University of Toronto Press; 2008. p. 243-56.

49. Spears T. Northern Ontario MDs seek solution to region's huge accidental-death toll. CMAJ. 1996;155:101-2.

50. Rodgers GB. The characteristics and use patterns of all-terrain vehicle drivers in the United States. Accid Anal Prev. 1999;31:409-19.

51. Helmkamp JC. Adolescent all-terrain vehicle deaths in West Virginia, 1990-1998. W V Med J. 2000;96:361-3.

52. All Terrain Vehicle (ATV) Injuries resulting in hospitalization on the rise, reports Canadian Institute for Health Information [Internet]. Canadian Institute for Health Information; 2003 [cited 2008 Aug 10]. Available from: http://secure.cihi.ca/cihiweb/.

53. Centers for Disease Control and Prevention. All-terrain vehiclerelated deaths--West Virginia, 1985-1997. MMWR. 1999;48:1-4.

54. Carr AM, Bailes JE, Helmkamp JC, Rosen CL, Miele VJ. Neurological injury and death in all-terrain vehicle crashes in West Virginia: a 10-year retrospective review. Neurosurgery. 2004;54:861-7. 